\title{
Correction: Preliminary programme evaluation of the Scottish Clinical Leadership Fellowship
}

Pearson A, Ryan C, MacVicar R. Preliminary programme evaluation of the Scottish Clinical Leadership Fellowship. BMJ Leader 2018;2:40-2. doi:10.1136/leader-2018-000038.

The fourth author was added in error and has been removed.

(c) Article author(s) (or their employer(s) unless otherwise stated in the text of the article) 2018. All rights reserved. No commercial use is permitted unless otherwise expressly granted.

BMJ Leader 2018;2:83. doi:10.1136/leader-2017-000038corr1

(D) Check for updates 